\title{
Price premium of organic salmon in Danish retail sale
}

\author{
Isaac Ankamah-Yeboah *, Max Nielsen, Rasmus Nielsen \\ Department of Food and Resource Economics, Faculty of Science, University of Copenhagen, Rolighedsvej 25, 1958 Frederiksberg C, Denmark
}

\section{A R T I C L E I N F O}

\section{Article history:}

Received 13 July 2015

Received in revised form 13 October 2015

Accepted 19 November 2015

Available online $\mathrm{xxxx}$

\section{Keywords:}

Price premium

Organic aquaculture

Fishery eco-label

Salmon

\begin{abstract}
A B S T R A C T
The year 2016 will be pivotal for organic aquaculture producers in EU, because it represents the deadline for implementing the complete organic life cycle in aquaculture production. Depending on the sturdiness of farms already producing, such a shift in the industry may affect production costs of exclusively using organic fry for production. If the profitability of the primary organic aquaculture producers should be maintained, then farmers must be able to correspondingly receive higher prices, transmitted through the value chain from the retail market. This study identifies the price premium for organic salmon in Danish retail sale using consumer panel scanner data from households by applying a random effect hedonic price model that permits unobserved household heterogeneity. A price premium of $20 \%$ was identified for organic salmon. The magnitude of this premium is comparable to organic labeled agricultural products and higher than that of eco-labeled capture fishery products, such as the Marine Stewardship Council. This indicates that the organic label also used for agricultural products may be better known and trusted among consumers than the eco-labels on capture fishery products.
\end{abstract}

(c) 2015 Elsevier B.V. All rights reserved.

\section{Introduction}

The year 2016 will be pivotal for the European Union organic aquaculture sector. According to Commission Regulation (EU) No 1364/ 2013, the full life cycle from the time the fish hatches to when it is slaughtered must be $100 \%$ organic from 1 st January 2016 , if the product is to be recognized and marketed as an organic certified product. Today only grow out stages of aquaculture production need to be organic to achieve this label. The regulation of exclusively using organic fry is expected to challenge the organic aquaculture producers in that the organic rules only allow limited use of antibiotics and requires specially made organic feed. As such, the new regulation will most likely induce higher cost in terms of higher fry mortality, feed costs and management effort.

In light of this transition, the existence of a price premium could incentivize producers and facilitate subsequent conversion of conventional farms into organic farms and maintain already existing organic farms. The necessary conditions for the price premium existence are consumers ability to identify organic goods at retail sale (i.e., through labeling), and the willingness to pay extra price relative to the conventional salmon. Furthermore, the price premium must be transmitted through to all actors in the value chain, i.e. if the organic salmon market is to be maintained, all actors in the chain must gain from it (Asche et al., 2015).

\footnotetext{
* Corresponding author.

E-mail addresses: iay@ifro.ku.dk (I. Ankamah-Yeboah), max@ifro.ku.dk (M. Nielsen), rn@ifro.ku.dk (R. Nielsen).
}

The purpose of this article is to reveal whether a price premium exists for organic farmed salmon products in the Danish retail market. The magnitude of the estimated price premium is discussed in light of the premium attributed to other eco-labels such as in organic agriculture, fisheries (e.g., the Marine Stewardship Council) and aquaculture eco-labels (i.e., organic and the Aquaculture Stewardship Council) found in literature. The workhorse for the study is the hedonic price model.

The study provides an important contribution to the hedonic literature on eco-labels for seafood mainly conducted in the United Kingdom. In contrast to stated preference studies which identifies hypothetical willingness to pay, this study provides evidence of "revealed" organic price premiums; an evidence important for fish farmers and actors in the value chain in an emerging organic aquaculture market. Although this study has direct benefits for producers in Norway, ${ }^{1}$ Scotland and the Faroe Islands in the case of salmon, it informs producers about the market potential of substitute products such as organic trout where Denmark is the leading producer.

Environmental friendliness has for the last 2-3 decades been a major part of the food production process and consumer food choice decisions, more recently also being introduced in the seafood sector. Despite the established importance of seafood as a global source of protein, nutrition and other health benefits (Food and Agriculture Organization, 2014; Daviglus et al., 2002; Brunsø et al., 2008), there

\footnotetext{
${ }^{1}$ Norway, though not a member, follows the EU rules on organic aquaculture, because the EU market is the most important export market.
} 
has been growing concerns about the environmental impact of the production process (Asche et al., 2015; Roth et al., 2000; Asche and Bjorndal, 2011). The traditional "command and control" fishery and aquaculture management instruments have been recognized as inadequate in their own in terms of addressing these concerns. Thus, market-based incentive regulation such as individual transferable quotas (Anderson, 1994; Turner, 1996; Smith, 2012; Nielsen, 2011, 2012 and Nielsen et al., 2014) and the use of information, such as eco-labeling, have been called upon as an alternative to traditional methods of regulating environmental externalities.

Eco-labeling helps to establish product differentiation by making the credence attribute production method (organic/conventional) visible to the consumer and contributes to mitigating potential inefficiencies resulting from imperfect information (e.g. information asymmetry between producers and consumers) about the environmentally friendly production processes of a good. Because such production processes are typically more costly than conventional standards, producers undertaking these methods need increased earning. Hence, the aim of eco-labeling is to increase profits by attracting environmentally responsible consumers who are willing to pay a price premium to support a costlier production process, while attaining utility.

The most dominant and studied eco-label in the seafood sector is the Marine Stewardship Council (MSC) in the fisheries sector (MSC, 2014, Roheim et al., 2011). The Aquaculture Stewardship Council (ASC), established in 2010, is also emerging for farmed fish (ASC, 2014) but yet to be studied, given that the first certification was only launched in 2012 for tilapia in Indonesia. Following the introduction of EU Regulation 710/2009 in 2010, the EU organic aquaculture eco-label was also introduced. However, there are many other national and private aquaculture labels. To build on consumer confidence, certified organic farmed fish in Denmark are labeled with the well-established and well-known label, a red-Ø (Christensen et al., 2014), which is issued, enforced and controlled by the Danish government.

Most studies rely on stated preference methods to establish willingness to pay for eco-labeling in the seafood market (e.g., Olesen et al., 2010). Those relying on actual market data (i.e., revealed preference methods) are limited, but evidence provided in the fishery sector includes the existence of an approximately $13 \%$ price premium for salmon (Asche et al., 2015) and cod and haddock (Sogn et al., 2014), a $10 \%$ premium for chilled haddock (Sogn-Grundvåg et al., 2013) and a 14\% premium for frozen Alaska pollock (Roheim et al., 2011) in the UK market for MSC-labeled fish. A mean price difference of $10 \%$ is estimated for MSC Baltic cod in Sweden (Blomquist et al., 2015). For organic salmon, an approximately $25 \%$ price premium is found in the UK (Asche et al., 2015). Price premia of $24 \%$ and $38 \%$ for organic fresh and smoked salmon respectively, have been identified in Norway (Aarset et al., 2000). On eco-labeled agricultural products, there is evidence of price premiums ranging from $15-60 \%$ in the UK and Danish markets for various products (Wier et al., 2008 and Baltzer, 2004). Generally, organic price premiums for agricultural products appear to be larger than the range of $10-14 \%$ identified for fishery eco-labels.

Using consumer panel data, this study establishes that there is a price premium of approximately $20 \%$ for organic salmon. The magnitude of the premium might indicate that consumers value organic farmed fish as in the same range as agricultural products, rather than in the same range as fishery products. The magnitude might also indicate that the Danish organic Ø-label is better-established and more accepted among Danish consumers than the MSC-label. The higher cost of producing organic fish has to be compensated by a higher willingness to pay from consumers. Hence, the high price premium of organic salmon on $20 \%$ is good news for producers, provided the price premium is transmitted from consumers, through the value chain to primary producers.

The article is organized as follows. The next section introduces the Danish seafood market, followed by a description of data used for the analysis. The theoretical model and the empirical specification are then discussed. Next the empirical results are presented. Finally, Section 7 presents the conclusion.

\section{The Danish Seafood Market}

Denmark is the eighth largest exporter of fish and fishery products in the world (FAO, 2014) with about $80 \%$ of Danish exports staying in the EU. It is a major importer of raw materials used for further processing and then re-exported. In 2013, export of fish and fishery products was DKK 21.5 billion, where import formed DKK 15.5 billion. Most imports originate from the countries surrounding the western part of the North Atlantic Ocean with Norway being the largest. Hence, Denmark is an intermediate market in the seafood value chain, with substantial seafood processing but also with important primary fishery and aquaculture sectors. Seafood processing and wholesale in Denmark is mainly made for the EU market, implying that the Danish home market becomes a residual market that is only supplied with a small fraction of what is produced in Denmark (Nielsen, 2005).

The Danish aquaculture sector has a well-established tradition of fish production that dates back more than a century (Hessel, 1993). Aquaculture production concentrates on rainbow trout, farmed freshwater. Blue mussels, sea trout, chars and pike perch are produced in modest quantities, with several marine fish and mussel farms. The total annual production is approximately 43,000 tons, of which $90 \%$ is rainbow trout (Statistic Denmark, 2014). The EU is the most important market with Germany being the largest destination market (Nielsen et al., 2011, 2012). In 2014, Denmark became the largest producer of organic trout, passing France with a production volume of 1080 tons. Organic mussel farms produce approximately 400 tons per annum.

Production of salmon is modest and no organic salmon is produced locally. Norway and the Faroe Islands are the most important fresh salmon markets serving the Danish import demand. The import of salmon is fairly evenly divided into fish that are re-exported with little or no processing and fish that are used for processing, and mostly re-exported in processed form. As a result, Denmark is the second largest exporter of salmon in Europe after Norway (Asche and Bjorndal, 2011). According to Statistic Denmark, more than $80 \%$ of the volume of salmon imports into Denmark is farmed fresh or chilled Atlantic salmon. The local market for fish consumption is limited due to its small population; however, the per capita consumption of $24 \mathrm{~kg} / \mathrm{year} /$ per capita is relatively high.

Domestic supply outlets include supermarket chains, independent fish-mongers/specialized stores, online retailing, restaurants and catering services. Supermarket outlets command the largest share, accounting for $85 \%$ of the total domestic supply. According to Brunsø et al. (2008), the most frequently consumed fish species and their shares of consumption are herrings (22\%), tuna (19\%), mackerel (17\%), salmon (11\%) and plaice (10\%). Canned, marinated and fresh filleted fish are the three most frequent product categories. The total domestic fish consumption in 2008 was approximately 127,000 tons. Salmon was estimated to be the most consumed fish in terms of value in Denmark followed by cod with respective values of DKK 1.2 billion and DKK 940 million. The value shares of salmon were $44 \%$ for fresh salmon, $39 \%$ for smoked salmon and $17 \%$ for frozen salmon (Anon, 2011).

Danish consumers have a long tradition for buying organic food products. The country continues to rank second in terms of per capita organic food consumption (DKK 1223/person) and first in terms of organic market share $(8 \%)$ in the retail market worldwide (Willer and Lernoud, 2015). The most important organic fish species produced in Denmark, trout, hit the retail market in 2005 (Larsen, 2014). Domestically produced organic fish are labeled with the Danish red-Ø-label, which is well known and accepted among consumers. MSC and ASC eco-labels can also be found on retail shelves. The consumption of fish among Danes is motivated by health benefits, availability, convenience, taste, traditions and in contrast, high prices deter consumers from purchasing (Nielsen, 2000). The frequency of fish consumption of elderly people is at least twice that of young people (Olsen, 2004). On 
average, the consumption frequency is 1.4 times per week compared to the European average of 1.5 and the recommended level of two times per week (Brunsø et al., 2008).

\section{Data}

Consumer scanner data were used to determine the existence and magnitude of the retail price premium for organic labeled salmon products. The use of scanner data from the retail sale of products became widely employed in the 1980s (Roheim et al., 2011). The data used in this study originate from GfK Panel Services Denmark, which maintains a demographically representative consumer panel of Danish households. We consider an emerging organic fish market for which observations have been recorded only since 2011 . Hence, observations span from 1 January, 2011 to 31 December, 2013. The data contain the daily purchases of over 2000 households, with approximately $20 \%$ of the households replaced each year by a similar type of households. The data are a refreshed panel data. ${ }^{2}$ Unlike traditional panel data, we observe repeated time values that cannot be aggregated over time to provide unique values (i.e., households report multiple purchases at a single point in time for salmon products with different characteristics). ${ }^{3}$ Aggregation would lead to a loss of information, especially for organic products because they represent a small fraction of the total observations. Because households do not purchase goods in a continuum of time, say every week, observations are reported in irregularly spaced time intervals to reflect shopping trips and purchasing behavior over time.

For each shopping trip, the household reports food purchases, including the date and time of the purchase, the shop name, the expenditure and the volume of the product purchased. For each unit of salmon purchased, households report information on whether the product was labeled as organic; a brand or private label; fresh or frozen; smoked, marinated, breaded, stuffed or processed in another form; filleted or whole-fish; and, purchased on a special offer or at the normal price. Summary statistics for the data and descriptions of the variables obtained to estimate the model are presented in Table 1 . The GfK data does not identify the type of organic label (e.g., the Danish Ø-red logo) indicated on the product. ${ }^{4}$ Likewise, the name of the brand or private label is not identified. The private and brand label attributes have no relation with organic or any environmental labels, but does identify whether the package label was that of the supplier (i.e., brand label) or customized to the retailer (i.e., private label).

After subsampling household salmon purchases and removing unusable observations (such as observations without any descriptive information and, errors/outliers in the data), we were left with 18,471 observations from 2342 households. The volume of the purchase measured in grams was converted to kilograms, and the value of purchase was divided by the volume to retrieve the price per kilo $(\mathrm{DKK} / \mathrm{kg})$. The means of the dummy variables shown in Table 1 represent the fraction of the total observations for the respective attributes. For instance, organic salmon products represent approximately $0.3 \%$ of the total number of observations used in the analysis. Salmon fillets make up approximately $90 \%$ relative to whole-fish purchases. The organic market share of the data was approximately $0.5 \%$ of the total salmon market sales in volume. Inflation over the study period was quite low; hence, we do not expect it to affect food prices much in this short period. Therefore, the model was estimated with the nominal market prices.

\footnotetext{
2 See Fitzmaurice et al. (2012) and Frees (2004) for a discussion of features of data types with repeated observation.

${ }^{3}$ This presents a challenge in modeling the time series property of the data such as autocorrelation. Autoregressive models are less appealing for unequally spaced data.

${ }^{4}$ The ASC and MSC eco-labels though available on retail shelves were not identified in the GfK data. Also no distinction could be made for wild and farmed salmon. However, since most of Denmark's imports are farmed Atlantic salmon coming from Norway, Scotland and Faroe Islands, we do not expect any influence on the conclusion of the results.
}

Table 1

Summary statistics and variable descriptions.

\begin{tabular}{|c|c|c|c|}
\hline Variables & Mean & $\begin{array}{l}\text { Std. } \\
\text { dev }\end{array}$ & Variable description \\
\hline Price_Dkkkg & 158.73 & 65.50 & Price measured in DKK per kg \\
\hline Organic price & 190.98 & 109.06 & Price of organic salmon in DKK per kg \\
\hline Conv. price & 158.63 & 65.31 & Price of conventional salmon in DKK per $\mathrm{kg}$ \\
\hline $\operatorname{Ln}($ price $)$ & 4.98 & 0.44 & Log of price \\
\hline Volume (Vol) & 0.28 & 0.23 & Volume purchased in $\mathrm{kg}$ \\
\hline Organic (Org) & 0.003 & - & Dummy variable: 1 if organic, 0 otherwise \\
\hline Brand $(\mathrm{Br})$ & 0.77 & - & $\begin{array}{l}\text { Dummy variable: } 1 \text { if brand label, } 0 \text { private } \\
\text { label }\end{array}$ \\
\hline Fresh (Fr) & 0.86 & - & Dummy variable: 1 if fresh, 0 frozen \\
\hline Pr_smoked (Prc) & 0.50 & - & Dummy variable: 1 if smoked, 0 otherwise \\
\hline $\begin{array}{l}\text { Pr_marinated } \\
(\operatorname{Prc})\end{array}$ & 0.22 & - & Dummy variable: 1 if marinated, 0 otherwise \\
\hline Fm_fillet (Fi) & 0.90 & - & Dummy variable: 1 if fillet, 0 whole-fish \\
\hline Specoffer (Sp) & 0.45 & - & $\begin{array}{l}\text { Dummy variable: } 1 \text { if on special offer, } 0 \\
\text { normal price }\end{array}$ \\
\hline Year_2012 & 0.36 & - & Dummy variable: 1 if year 2011,0 otherwise \\
\hline Year_2013 & 0.34 & - & Dummy variable: 1 if year 2012,0 otherwise \\
\hline Year_2011 & 0.30 & - & Dummy variable: 1 if year 2013,0 otherwise \\
\hline Season1(Se) & 0.23 & - & Dummy variable: 1 if quarter 1,0 otherwise \\
\hline Season2 (Se) & 0.26 & - & Dummy variable: 1 if quarter 2,0 otherwise \\
\hline Season3 (Se) & 0.23 & - & Dummy variable: 1 if quarter 3,0 otherwise \\
\hline Season4 (Se) & 0.24 & - & Dummy variable: 1 if quarter 4,0 otherwise \\
\hline
\end{tabular}

Notes: The abbreviations in parentheses were used in the model expression (see below). Source: Authors' own calculation.

\section{The Hedonic Price Model}

Recognizing the inability of neoclassical theory of consumer demand to explain why consumers derive utility from commodities and predicting the demand for new products, the characteristics theory (hedonic price model) was proposed by Lancaster $(1966,1971)$ to address some of these inherent limitations (Smith et al., 2009). Although Bartik (1987) notes that the first formal contributions to hedonic price theory were made by Court (1941) and Tinbergen $(1951,1956)$, an earlier application has been attributed to Waugh (1928), who studied the quality factors influencing the prices of vegetables. The introductory section by Waugh (1928) also makes note of earlier applications for other agricultural commodities. However, the application of the hedonic model was pioneered by Rosen (1974) and has since been widely used in the literatures on housing, environmental economics and, labor markets and has gained attention in marketing and industrial organization (Bajari and Benkard, 2005). The Lancastrian theory presumes that consumption is an activity for which goods, singly or in combination, are inputs and the output is a collection of characteristics. This theory plays a crucial role in and lays the necessary conceptual framework for the development of modern hedonic analysis (Huang and Lin, 2007). Rosen further refined this theory with a particular emphasis on market equilibrium.

The hedonic approach postulates that goods are made up of a myriad of attributes that combine to form a bundle of characteristics that the consumers value. The demand for various desired characteristics can be estimated from consumers' willingness to pay for a product. As such, the marginal or implicit values can be imputed for each attribute at the observed purchase price linked to the myriad of attributes contained in the good. The hedonic model operates on the premise that consumers and producers consider the same set of attributes when valuing a good. As a result, the choices each group makes lead to an equilibrium condition that neither have any incentive to change. The equilibrium price determination introduced by Rosen (1974) requires simultaneous estimation of both supply and demand equations. Following Wilson (1984), we make the implicit assumption that the supply of product attributes is perfectly inelastic with respect to its marginal implicit price in any given time period. Given such an assumption, the empirical hedonic price model requires only market clearing prices rather than both demand and supply schedules (Kim and Chung, 2011). 
The retail market for salmon meets consumers' needs by differentiating products. Products are presented with different brand labels, eco-labels, processed forms and other desirable characteristics. Due to the heterogeneous nature of the products, the determination of an organic premium from observations of prices alone becomes a challenge. The hedonic framework permits the estimation of a price premium for organic characteristic that is distinct from the other characteristics. Consider a consumer's purchase of a unit of salmon. Salmon consists of $n$ component characteristics: $z=z_{1}, z_{2}, \ldots z_{n}$. Consumers maximize utility subject to a nonlinear budget constraint ${ }^{5}$ where utility is a function of a numeraire good, $x$, and the purchase of the differentiated good, $z$ (the vector of characteristics). Thus,

$\max U(x, z) \quad$ s.t. $\quad m=x+p\left(z_{k}\right)$

where $m$ represents the total income available and the consumer is assumed to choose a bundle of good and the goods in which the good's characteristics maximize utility. Utility is maximized when the marginal rate of substitution between a characteristic $\left(z_{k}\right)$ of the product and the composite good is equal to the marginal price of $z_{k}$. The solution to the first-order conditions from the constrained optimization for price yields the standard hedonic price equation:

$p_{i}=f\left(z_{k}\right)$

where the price of a heterogeneous good is a function of product characteristics. The derivative of price with respect to the $k t h$ characteristics yields, ceteris paribus, the implicit marginal price of that characteristic. Our goal is to estimate Eq. (2), also known as the first-stage hedonic price function. In this stage, the observed market clearing prices are regressed on the product characteristics. ${ }^{6}$ The derivative of price with respect to an attribute gives the marginal implicit price of that attribute.

\section{Empirical Model Specification}

Generally, economic theory does not provide guidance for the specification of the functional form of the hedonic price model. Although some researchers make assumptions of the functional form, this can lead to incorrect conclusions; therefore, using the data to determine the appropriate functional form is recommended (Faux and Perry, 1999). The Box-Cox transformation of the dependent variable which improves the normality of a variable (Box and Cox, 1964, 1982), was used in this paper to test for the functional form where the log-linear model is selected over other alternatives. This functional form makes it easier to interpret parameter estimates and shows the nonlinear relationship between prices and product attributes. Following this, we expand the hedonic price function in Eq. (2) in a log-linear form of the salmon price for product iat timet, represented as follows:

$$
\begin{aligned}
\ln p_{i t}= & \alpha+b V o l_{i t}+\beta \operatorname{Org}_{i t}+\delta \mathrm{B} r_{i t}+\varnothing F r_{i t}+\sum_{n=1}^{p-1} \gamma_{n} \operatorname{Prc}_{i t}+\varphi \mathrm{Fi}_{i t} \\
& +c S p_{i t}+\sum_{j=1}^{s-1} \theta_{j} S e_{i t}+e_{i t}
\end{aligned}
$$

The equation above is estimated by ordinary least squares where the descriptions of the variables are as presented in Table 1. Because the data spans multiple years, it is possible to include year dummies to exploit year to year price changes. The estimation of Eq. (3) is based on the assumption of independent observations.

\footnotetext{
${ }^{5}$ The nonlinearity of the budget constraint fulfills that arbitrage of characteristics is not possible. Hence, product attributes cannot be disentangled and repackaged.

6 The derivative of the variable Volume describes the responsiveness of price in relation to the average purchased value (to the size of the purchase), i.e., not to total quantities supplied. Hence, it has nothing to do with own price flexibilities as defined by Anderson (1980) and as estimated e.g., in Nielsen et al. (2012).
}

The data represent a structure where the reported observations or purchases of salmon are nested within households. In such a situation, observations from household units are most likely non-independent. Thus, observations from the same household are more likely to be similar than observations from different households. The estimation of non-independent observations with ordinary least squares methods leads to incorrect conclusions because the parameter estimates and their standard errors become biased and inefficient (Andreß et al., 2013; Musca et al., 2011). We therefore consider the class of longitudinal models able to account for such a nesting structure in the data and operate on the assumption of independence across household units but not within each household's observations. The basic idea in this application is that there may be some natural unobserved household heterogeneity that allows households to choose prices that may be above or below the average market price. For instance, households may be naturally attracted to shops with higher/lower salmon prices than the average. Alternatively, organic consuming households are more likely to choose organic products on subsequent shopping trips than non-organic households.

The choice of models used to handle the unobserved characteristic (i.e., household heterogeneity) is usually the fixed effect and random effect models. Whereas fixed effects analysis supports only inferences about the sampled households, random effects analysis allows one to make inferences about the entire population from which the sample was drawn. The random effects analysis appears to fit our purpose because we are estimating the hedonic model to derive an organic premium for a representative population in Denmark. Therefore, we consider a variant of the random effects model called the mixed linear model $(\mathrm{MLM})^{7}$; a general class of models that takes into account the nesting structure (i.e., non-independence) of the data. The mixed linear model with 2 level modeling; observed salmon prices (level 1 unit) nested in households (level 2 unit) is considered. Most often both the unconditional and conditional models are estimated to estimate the amount of variation explained by the independent variables. The unconditional random intercept model can be written as follows:

$\ln P_{i j}=a+u_{j}+e_{i j} ; \quad i=1 \ldots n$ products, $j=1 \ldots . . m$ households

The conditional model with the product attributes is also specified by expanding Eq. (4) as follows:

$$
\begin{aligned}
\ln P_{i j}= & a+b \operatorname{Vol}_{i j}+\beta \operatorname{Org}_{i j}+\delta \mathrm{Br}_{i j}+\phi \mathrm{Fr}_{i j}+\sum_{n=1}^{p-1} \gamma_{n} \operatorname{Prc}_{i j}+\varphi \mathrm{Fi}_{i j}+c S p_{i j} \\
& +\sum_{h=1}^{s-1} \theta_{h} S e_{i j}+u_{j}+e_{i j}
\end{aligned}
$$

In Eqs. (4) and (5), we change the notation of subscripts to denote household $j$ (level 2 unit) observing the purchase of product $i$ (level 1 unit) at multiple occasions. In simple terms, if one considers an intercept only model of Eq. (3), then the purchase of product $i$ by household $j$ is given by a function of the market wide price $a$ plus a differential $u_{j}$ for each household $j$ (referred to as unobserved household heterogeneity or level 2 unit or household residuals): $\alpha=a+u_{j}$. The right side of Eq. (5) can therefore be divided into two parts in the language of mixed models: (1) fixed effects (comprising of the parameters to be estimated) and (2) random effects (made up of the level 2 residuals and the idiosyncratic error/level 1 residuals, $e_{i j}$ ). The error terms are assumed to be normally distributed: $u_{j} \sim N\left(0, \sigma_{u}^{2}\right)$ and $e_{i j} \sim N\left(0, \sigma_{e}^{2}\right)$.

The model can be expanded by including the household unit characteristics as explanatory variables, but this is not the focus of this study

\footnotetext{
${ }^{7}$ Estimation was done in Stata where MLM is able to handle singleton observations within panels unlike the traditional random effects model, which is important to prevent loss of information.
} 
because we are modeling equilibrium prices based on the assumption that the consumer and producer are operating optimally such that none can alter prices. Additionally, the first-stage of the hedonic model is traditionally an estimation of prices on product characteristics. A major problem often associated with panel data is the issue of temporal autocorrelation. Though the mixed linear model provides more opportunities to estimate various covariance structures with time variation (autoregressive models), we are limited because the repeated time structure of the data does not permit us to test for the presence of autocorrelation. ${ }^{8}$ However, given that the data are a rotating panel where some households appear once in the three years, it is intuitively plausible to rule out the presence of autocorrelation. Estimation of Eq. (5) is based on the assumption that the value of the organic eco-label is independent of the retail chain as found in Asche et al. (2015).

\section{Estimation Results}

Reports on the coefficient estimate and goodness-of-fit of the models estimated from Eq. (3) (OLS) and 5 (MLM) are shown in Table 2. Overall, both models were highly significant; a joint test of all independent variables significance shows a P-value $<0.01$ using an F-test for OLS and Chisquare test for the MLM. The OLS model showed an $\mathrm{R}^{2}$ of approximately 0.48 , indicating that the independent variables explain approximately $48 \%$ of the total variation in prices. The MLM model presents two different $\mathrm{R}^{2}$ for the level 1 and level 2 units. The computed Snijders and Bosker $(1994,1999) R^{2}$ indicates that the independent variables explain approximately $48 \%$ of the variation in prices while the unobserved household heterogeneity (level 2 unit) explains approximately $52 \%$ of the variation in prices. A likelihood ratio test of $\mathrm{Ho}: \mathrm{O}_{u}^{2}=0,{ }^{9}$ rejected the null indicating that a model with unobserved household heterogeneity provides a better fit. The intra-class correlation not reported in the MLM estimation output was 0.29 , indicating the correlation of prices reported by the same household. Variants of the models were estimated with the inclusion of year dummies and, weekly and monthly trends to control for price changes. However, these were not significant and therefore have been dropped from the model.

The values reported for the Akaike Information Criterion ${ }^{10}$ for the two models presented in Table 2 indicate that the MLM provides the better fit. Given this selection, we restrict the interpretation of the parameter estimates to the MLM model. However, one can see that there is robustness in the parameter estimates between OLS and the MLM except for the organic variable. The parameters were estimated by acknowledging the presence of heteroscedasticity; hence heteroscedastic (cluster for MLM) robust standard errors were estimated.

All parameter estimates of product attributes appear to have the expected sign, according to economic theory or logical reasoning. Considering the volume of salmon products purchased, we observed a negative parameter estimate that is significant at the $5 \%$ level. The negative relationship between volume and the natural logarithm of price is an indication of a nonlinear price-discount due to the size of the purchase. The larger the quantity of a product purchased, the lower the marginal increase in price. Depending on the initial volume of salmon purchased, the extra kilogram purchased could be discounted by approximately $50 \%$, ceteris paribus.

We interpret the parameters of the dummy variables as the percentage premium as recommended by Halvorsen and Palmquist (1980) and computed as: Percent Premium $=\left(\exp ^{\theta}-1\right)^{*} 100$, where $\theta$ is the estimated parameter of the respective variables. The parameter for the organic variable indicates that there exists a price premium for organic

\footnotetext{
${ }^{8}$ In repeated time value data with sparse observations, it is unappealing to use time series operators such as lags or differences.

9 If $\sigma_{u}^{2}=0$, then the linear regression model (OLS) provides a better fit (thus the $u_{j}$ should be omitted from the model).

10 Bayesian Information Criterion values not reported show a similar pattern.
}

Table 2

Parameter estimates.

\begin{tabular}{|c|c|c|c|c|c|}
\hline \multirow[b]{2}{*}{ Variables } & \multicolumn{2}{|l|}{ OLS } & \multicolumn{3}{|l|}{ MLM } \\
\hline & $\begin{array}{l}\text { Coefficient } \\
\text { estimate }\end{array}$ & $\begin{array}{l}\text { Robust } \\
\text { std. } \\
\text { error }\end{array}$ & $\begin{array}{l}\text { Coefficient } \\
\text { estimate }\end{array}$ & $\begin{array}{l}\text { Cluster } \\
\text { rob. std. } \\
\text { error }\end{array}$ & $\begin{array}{l}\text { Percent } \\
\text { premium }\end{array}$ \\
\hline Volume (kg) & $-0.505^{* * *}$ & 0.021 & $-0.503^{* * *}$ & 0.028 & \\
\hline Organic & $0.363^{* * *}$ & 0.033 & $0.180^{* * *}$ & 0.061 & $19.7 \%$ \\
\hline Fresh & $0.294^{* * *}$ & 0.008 & $0.263^{* * *}$ & 0.011 & $30.1 \%$ \\
\hline Pr_marinated & $0.265^{* * *}$ & 0.008 & $0.258^{* * *}$ & 0.011 & $29.4 \%$ \\
\hline Pr_smoked & $0.248^{* * *}$ & 0.007 & $0.239^{* * *}$ & 0.011 & $27.0 \%$ \\
\hline Fm_fillet & $0.072^{* * *}$ & 0.008 & $0.053^{* * *}$ & 0.010 & $5.4 \%$ \\
\hline Brand label & $0.015^{* * *}$ & 0.006 & $0.021^{* * *}$ & 0.008 & $2.1 \%$ \\
\hline Special offer & $-0.240^{* * *}$ & 0.005 & $-0.198^{* * *}$ & 0.007 & $-17.3 \%$ \\
\hline Season1 & -0.001 & 0.007 & -0.005 & 0.006 & $-0.5 \%$ \\
\hline Season2 & $-0.014^{* *}$ & 0.006 & $-0.013^{* *}$ & 0.006 & $-1.3 \%$ \\
\hline Season3 & $0.034^{* * *}$ & 0.007 & $0.026^{* * *}$ & 0.006 & $2.6 \%$ \\
\hline Constant & $4.712^{* * *}$ & 0.015 & $4.718^{* * *}$ & 0.019 & \\
\hline$\sigma_{u}^{2}$ & & & 0.030 & & \\
\hline$\sigma_{e}^{2}$ & & & 0.074 & & \\
\hline AIC & 9777 & & 6941 & & \\
\hline $\operatorname{Prob}\left(L R: \sigma_{u}^{2}=0\right)$ & & & 0.000 & & \\
\hline Prob $>F /\left(x^{2}\right)$ & 0.000 & & 0.000 & & \\
\hline$R_{1}^{2}$ & 0.477 & & 0.476 & & \\
\hline$R_{2}^{2}$ & & & 0.515 & & \\
\hline Observations & 18,471 & & 18,471 & & \\
\hline \# of households & & & 2342 & & \\
\hline
\end{tabular}

**, ${ }^{* *},{ }^{*}$ indicates significance at $\mathrm{p}<0.01, \mathrm{p}<0.05, \mathrm{p}<0.1$. MLM, mixed linear model.

salmon in retail markets in Denmark given that it is highly significant at the $1 \%$ level. Households in Denmark therefore pay a premium of $19.7 \%$ over the conventional salmon price after accounting for other good attributes. Estimates from the OLS indicate consumers would pay a premium of approximately $44 \%$ for organic salmon if one were to discard the assumption of non-independence arising from repeated observations from the same households.

A premium of approximately $20 \%$, as shown by the MLM estimation, is substantial compared to the premium that has been identified in literature with the MSC eco-label in the fisheries sector, which is in the range of $10-14 \%$. The value however, appears in the range of organic agricultural price premia identified in the Danish and UK retail market. Although it remains a matter of speculation, one possible explanation for this result might be that the organic label is well-established and that consumers are well-aware of it, while their knowledge on specific fish eco-labels, like the MSC and ASC eco-label, might be less. That might be backed up by the finding of Grunert et al. (2014) that most consumers only have a limited use of sustainability labels which might well include the well-known organic label and exclude the specific fish labels, MSC and ASC.

Salmon products were presented as either fresh or frozen products and the estimation indicates that households tend to attribute a higher value to fresh salmon products compared to frozen products. As shown above, fresh products commanded approximately $30 \%$ extra in price over frozen ones, ceteris paribus. Likewise, some value is added to products to meet the heterogeneous preferences of consumers by further processing. Processed product groups identified in the data were marinated, smoked, breaded, stuffed and other unidentified products. The last three of these processed products were not significantly different in price valuations, so they were combined as the reference group. The results indicate that salmon consuming households in Denmark have a greater preference for smoked and marinated salmon. The smoked and marinated salmon product commanded approximately $27 \%$ and $29 \%$ extra in price, respectively, compared to the stuffed, breaded and other processed products, holding other attributes fixed. Roheim et al. (2011) argued based on similar results that the so called "value added" products such as breading, battering or stuffing could actually be a process form that masks some of the quality control issues generated along the supply chain, thereby belittling the level of consumer trust. Alternatively, it is also quite likely that the added 
non-fish ingredient is less costly than the fish ingredient, contributing to a lower price for the value added. Also the process of smoking adds costs in itself and contributes to the price difference.

Product branding has in the last decades become a marketing tool for differentiating products by retailers. Salmon products are identified with supplier brand labels. However, retail chains have preferences for their own custom private labeling from the main producers. The data therefore distinguishes products with brand labels from private labels. Our analysis reveals that significant differences exist between the two labels, with consumers valuing the brand labels by approximately $2 \%$ extra after controlling for other product attributes. Brand and private labels are competition strategies in the retailing market. As stated in Sogn et al. (2014), private labels strategically may come as economy packs that seek a 'value for money' position with a low price and acceptable quality similar to the supplier brands. Alternatively, they may be used as premium labels to present the consumer with a greater choice and build retailing image. The former appears to be the case for Danish retailers in the salmon market. Similar evidence is found in the German market by Bronnmann and Asche (2015) where private labels are discounted as high as $20 \%$.

Moreover, consumers tend to like salmon fillets more than wholefish because they appear to place a value worth approximately $5 \%$ on fillets. This could be explained by the fact that fillets are more convenient and easier to prepare. As explained earlier, convenience is a major determinant for seafood consumption among Danish consumers, and it is no surprise one would pay more for fillets compared to whole-fish. Sometimes, salmon products were sold in the retail chains at a discount for various reasons. The magnitudes of the discounts differ with retail shops and as they near the expiry dates. Controlling for discounted salmon products revealed that products were, on average, approximately $17 \%$ cheaper than the normal average market prices if discounted.

Lastly, we used quarterly dummies to account for seasonality, as defined in Table 1. It was evident that prices observed in the first season (January-March) were not significantly different from the reference season, season four (October-December). However, we observed that prices were significantly lower in season two (April-June) and higher in the third season (July-September). The third season appears to suit the summer season, when prices were higher than all the other periods. An expanded form of the model was estimated to examine the individual month-to-month variation in salmon prices. ${ }^{11}$ Prices were not significantly different from November to February and in March and April. Prices were significantly higher in the remaining months. The highest prices were observed in July and August, with respective premiums of $5 \%$ and $6 \%$ above the reference December prices. This was not surprising in that salmon to some extent is a seasonal commodity with most growth occurring in summer/early fall. ${ }^{12}$ As with other seasonally perishable commodities, volatility is greatest just prior to the period of harvest due to low stocks (Oglend, 2013). Hence, the generally held notion of boosted Christmas prices is not a general rule for the salmon market in Denmark, or Norway (Forsberg and Guttormsen, 2006).

\section{Conclusion}

In this study, a hedonic price model was used to disentangle the marginal values of salmon product attributes with the aim of identifying whether a significant price premium exists for organic products. A scanner data from consumers of salmon in the Danish retail market is used to estimate a random effect model and an ordinary least squares model. The former is selected based on model selection criteria. The findings indicate that there is an approximately $20 \%$ price premium for organic salmon compared to the conventional alternative.

\footnotetext{
11 This model was not presented since it neither changed the estimates of the other parameters nor the model fitness significantly.

12 Peak harvest periods occur in September and October.
}

It was also revealed from the estimation that the issue of convenience leads to valuing fillets more than whole-fish. Fresh products are valued higher than frozen. Marinated and smoked products are valued higher than breaded and stuffed product forms because these processed forms can mask the quality of fish along the supply chain. As a competition strategy, retailers make use of private labels as opposed to brand labels to provide consumers with economy valued products.

Valuing organic fish in the retail market presents first-hand motivating information for organic aquaculture producers given the potential change in the cost structure following the EU's full implementation of the organic aquaculture life cycle in 2016. However, because organic aquacultures supply an emerging market, it is expected that the size of the price premium will decrease, both with an increase in the supply of organic salmon and with a reduction in production costs over time following economies of scale. For farmers to receive the price premiums, the market must exhibit competitive behavior through the value chain, where premiums are transmitted to producers. Also, the governance structure along the global salmon value chain will determine the impact of the organic price margin to the chain actors.

In light of the literature on price premia for eco-labels in the fishery sector (i.e. MSC) and the agricultural sector (i.e. mainly organic), the value of the estimated premium is higher than the former and comparable to the latter. Although not studied and remaining a task for future research, this might indicate that consumer awareness and trust in the well-established and well-known organic label is transmitted to farmed fish from other food products. If this is correct and further assuming that Danish consumers have less knowledge and trust in the newer, specific fish labels MSC and ASC, the price premium of these are expected to be lower than for organic salmon.

Although the model specification appears good more research attention can increase the precision of the results and extend the scope of interpretation. First, price premiums are identified at the retail market, without assessing whether the premiums are transmitted through the value chain to fish farmers. Knowledge on the implication for organic salmon farmers and other businesses in the value chain on the existence of a price premium in retail sale, requires more knowledge on the nature of price transmission (i.e., speed and size), the global value chain governance structure of the organic salmon market and whether the size of the premium can cover extra costs. Second, the lack of data and evidence from the literature on MSC eco-labels in Denmark compelled us to compare the estimated price premium to fishery ecolabels in a different market (i.e., UK), a situation that is suboptimal. However, the similarities between the Danish and UK retail markets permit us to make this comparison to some extent. As portrayed by Wier et al. (2008), the two markets in Europe have greater shares of organic products distributed through mainstream conventional retail chains. They have concentrated organic food markets based on high proportions of imports and, in some cases, highly processed, largescale units of production, processing and distribution.

\section{Acknowledgment}

This work is part of the RobustFish project. RobustFish is part of the Organic RDD 2 program, which is coordinated by the International Centre for Research in Organic Food Systems (ICROFS). It has received grants from the Green Growth and Development program (GUDP) under the Danish Ministry of Food, Agriculture and Fisheries (J.nr.: 34009-13-0677).

\section{References}

Aarset, B., S. Beckmann, J., Bigne, M., Beveridge, T., Bjorndal, P., McDonagh, C., Mariojouls, et al., 2000. "Demand for organic salmon in the European Union.". Proceedings of the XIIth Annual Conference of the European Association of Fisheries Economists. Esbjerg: University of Southern Denmark, pp. 221-246 Accessed on 14/12/2015 via 
http://ir.library.oregonstate.edu/xmlui/bitstream/handle/1957/30734/070.pdf? sequence $=1$.

Anderson, R.W., 1980. Some theory of inverse demand for applied demand analysis. Eur. Econ. Rev. 14, 281-290.

Anderson, L.G., 1994. An economic analysis of highgrading in ITQ fisheries regulation programs. Mar. Resour. Econ. 209-226.

Andreß, H.J., Golsch, K., Schmidt, A., 2013. Applied Panel Data Analysis for Economic and Social Surveys. Springer.

Anon, 2011. Economic situation of the Danish fishery 2011. A Report From the Institute for Food and Resource Economics. University of Copenhagen.

Aquaculture Stewardship Council, 2014. Aquaculture Stewardship Council press release 16 December 2014. Last accessed on 13/10/2015 via http://www.asc-aqua.org/ upload/ASC_journey_to_100_certified_farms.pdf.

Asche, F., Bjorndal, T., 2011. The economics of salmon aquaculture vol. 10. John Wiley \& Sons.

Asche, F., Larsen, T.A., Smith, M.D., Sogn-Grundvåg, G., Young, J.A., 2015. Pricing of ecolabels with retailer heterogeneity. Food Policy 53, 82-93.

Bajari, P., Benkard, C.L., 2005. Demand estimation with heterogeneous consumers and unobserved product characteristics: a hedonic approach. J. Polit. Econ. 113 (6), 1239.

Baltzer, K., 2004. Consumers' willingness to pay for food quality-the case of eggs. Acta Agric. Scand. Sect. C 1 (2), 78-90.

Bartik, T.J., 1987. The estimation of demand parameters in hedonic price models. J. Polit. Econ. 81-88

Blomquist, J., Bartolino, V., Waldo, S., 2015. Price premiums for providing eco-labelled seafood: evidence from MSC-certified cod in Sweden. J. Agric. Econ.

Box, G.E., Cox, D.R., 1964. An analysis of transformations. J. R. Stat. Soc. Ser. B Methodol. 211-252.

Box, G.E.P., Cox, D.R., 1982. An analysis of transformations revisited, rebutted. J. Am. Stat. Assoc. 77 (377), 209-210.

Bronnmann, J., Asche, F., 2015. The value of product attributes, brands and private Labels: an analysis of frozen seafood in Germany. J. Agric. Econ. 2015.

Brunsø, K., Hansen, K.B., Scholderer, J., Honkanen, P., Olsen, S.O., Verbeke, W., Børresen, T., 2008. Consumer attitudes and seafood consumption in Europe. Improving Seafood Products for the Consumer, pp. 16-39.

Court, L.M., 1941. Entrepreneurial and consumer demand theories for commodity spectra: part I. Econometrica 135-162.

Christensen, T., Olsen, S.B., Kærgård, N., Dubgaard, A., 2014. Questionnaire on organic consumption. Frederiksberg: Institute for Food and Resource Economics. Copenhagen University, (IFRO Dokumentation; Nr. 2014/3) - In Danish.

Daviglus, M., Sheeshka, J., Murkin, E., 2002. Health benefits from eating fish. Comments Toxicol. 8 (4-6), 345-374.

Faux, J., Perry, G.M., 1999. Estimating irrigation water value using hedonic price analysis: a case study in Malheur County, Oregon. Land Econ. 440-452.

Fitzmaurice, G.M., Laird, N.M., Ware, J.H., 2012. Applied Longitudinal Analysis vol. 998. John Wiley \& Sons.

Food and Agriculture Organization, 2013. Fishery and Aquaculture Country Profiles: the Kingdom of Denmark. Fisheries and Aquaculture Department Available at http:// www.fao.org/fishery/facp/DNK/en.

Food and Agriculture Organization, 2014. State of World Fisheries and Aquaculture 2014. FAO Fisheries and Aquaculture Department, Rome.

Forsberg, O.I., Guttormsen, A.G., 2006. The value of information in salmon farming. Harvesting the right fish at the right time. Aquac. Econ. Manag. 10 (3), 183-200.

Frees, E.W., 2004. Longitudinal and Panel Data: Analysis and Applications in the Social Sciences. Cambridge University Press.

Grunert, K.G., Hieke, S., Wills, J., 2014. Sustainability labels on food products: consumer motivation, understanding and use. Food Policy 44, 177-189.

Halvorsen, R., Palmquist, R., 1980. The interpretation of dummy variables in semilogarithmic equations. Am. Econ. Rev. 70 (3), 474-475.

Hessel, V., 1993. Dansk ørrederhverv gennem 100 år. Skellerup, Arhus, Denmark.

Huang, C.L., Lin, B.H., 2007. A hedonic analysis of fresh tomato prices among regional markets. Appl. Econ. Perspect. Policy 29 (4), 783-800.

Kim, C., Chung, C., 2011. Hedonic analysis of retail egg prices using store scanner data: an application to the Korean egg market. J. Food Distrib. Res. 42 (3).

Lancaster, K.J., 1966. A new approach to consumer theory. J. Polit. Econ. 132-157.

Lancaster, K., 1971. Consumer Demand: A New Approach.

Larsen, J.V., 2014. Projekt: Udbredelse af information om økologisk fiskeopdræt i Danmark og aktuelle produkter herfra (ØKOFISK info). Dansk Akvakultur, Akvakultur Forum Faglig rapport fra Dansk Akvakultur nr. 2014-1.
Marine Stewardship Council, 2014. Marine Stewardship Council annual report 20132014. (Available at http://www.msc.org/documents/msc-brochures/annual-reportarchive/annual-report-2013-14-english, last accessed on 13/10/2015).

Musca, S.C., Kamiejski, R., Nugier, A., Méot, A., Er-rafiy, A., Brauer, M., 2011. Data with hierarchical structure: impact of intraclass correlation and sample size on type-I error. Quant. Psychol. Meas. 2, 74.

Nielsen, M., 2000. A review of research of market outlets for Nordic fishermen. Nordic Council of Ministers. TemaNord 2000:524.

Nielsen, M., 2005. Kortlænging af den globale Handel med Fisk og fiskeprodukter. FOI report no. 173. University of Copenhagen.

Nielsen, R., 2011. Green and technical efficient growth in Danish fresh water aquaculture. Aquac. Econ. Manag. 15 (4), 262-277.

Nielsen, R., 2012. Introducing individual transferable quotas on nitrogen in Danish fresh water aquaculture: production and profitability gains. Ecol. Econ. 75, 83-90.

Nielsen, M., Jensen, F., Setälä, J., Virtanen, J., 2011. Causality in demand: a co-integrated demand system for trout in Germany. Appl. Econ. 43 (7), 797-809.

Nielsen, M., Smit, J., Guillen, J., 2012. Price effects of changing quantities supplied at the integrated European fish market. Mar. Resour. Econ. 27 (2), 165-180.

Nielsen, R., Andersen, J.L., Bogetoft, P., 2014. Dynamic reallocation of marketable nitrogen emission permits in Danish freshwater aquaculture. Mar. Resour. Econ. 29 (3) 219-239.

Oglend, A., 2013. Recent trends in salmon price volatility. Aquac. Econ. Manag. 17 (3), 281-299.

Olesen, I., Alfnes, F., Røra, M.B., Kolstad, K., 2010. Eliciting consumers' willingness to pay for organic and welfare-labelled salmon in a non-hypothetical choice experiment. Livest. Sci. 127 (2), 218-226.

Olsen, S.O., 2004. Antecedents of seafood consumption behavior: an overview. J. Aquat. Food Prod. Technol. 13 (3), 79-91.

Roheim, C.A., Asche, F., Santos, J.I., 2011. The elusive price premium for ecolabelled products: evidence from seafood in the UK market. J. Agric. Econ. 62 (3), 655-668.

Rosen, S., 1974. Hedonic prices and implicit markets: product differentiation in pure competition. J. Polit. Econ. 34-55.

Roth, E., Nielsen, M., Pickering, H., Jaffry, S., Whitmarsh, D., Wattage, P., Frere, J., 2000. The value of fish quality. IIFET 2000 Proceedings.

Smith, M.D., 2012. The new fisheries economics: incentives across many margins. Annu. Rev. Resour. Econ. 4 (1), 379-402.

Smith, T.A., Huang, C.L., Lin, B.H., 2009. Estimating organic premiums in the US fluid milk market. Renewable Agric. Food Syst. 24 (03), 197-204.

Snijders, T.A.B., Bosker, R.J., 1994. "Modeled variance in two-level models". Sociol Methods Res. 22 (3), 342-363.

Snijders, T.A.B., Bosker, R.J., 1999. Multilevel analysis. An Introduction to Basic and Advanced Multilevel Modeling. Sage, London.

Sogn-Grundvåg, G., Larsen, T.A., Young, J.A., 2013. The value of line-caught and other attributes: an exploration of price premiums for chilled fish in UK supermarkets. Mar. Policy 38, 41-44.

Sogn-Grundvåg, G., Larsen, T.A., Young, J.A., 2014. Product differentiation with credence attributes and private labels: the case of whitefish in UK supermarkets. J. Agric. Econ. 65 (2), 368-382.

Statistic Denmark, 2014. Account statistics for aquaculture. http://webfd.fd.dk/stat/ Akvakultur_tab/prod_art_14_eng.html.

Tinbergen, J., 1951. Some remarks on the distribution of labour incomes. Int. Econ. Pap. 1 195-207.

Tinbergen, J., 1956. On the theory of income distribution. Weltwirtschaftliches Arch. $155-175$.

Turner, M.A., 1996. Value-based ITQ's. Mar. Resour. Econ. 59-69.

Waugh, F.V., 1928. Quality factors influencing vegetable prices. J. Farm Econ. 10 (2) $185-196$.

Wier, M., O'Doherty Jensen, K., Andersen, L.M., Millock, K., 2008. The character of demand in mature organic food markets: Great Britain and Denmark compared. Food Policy 33 (5), 406-421.

The world of organic agriculture, statistics and emerging trends 2015. In: Willer, H., Lernoud, J. (Eds.), FiBL-IFOAM Report. Research Institute of Organic Agriculture (FiBL), Frick, and IFOAM-Organics International, Bonn.

Wilson, W.W., 1984. Hedonic prices in the malting barley market. West. J. Agric. Econ. 9 (01). 